\title{
UDC 621.175
}

S. Sosnovskiy ${ }^{1}$ V. Kravchenko², DSc, Prof.

1 “Plastenergo" Research and Production Company, 23 Chapaeva Str., Kremenchug, Ukraine, 39609

${ }^{2}$ Odessa National Polytechnic University, 1 Shevchenko Ave., Odessa, Ukraine, 65044; e-mail: kravchenko@opu.ua

\section{STANDARD CONDITIONS TO DEFINE THE WATER COOLING SYSTEMS WITH MECHANICAL-DRAFT AND CHIMNEY-TYPE TOWERS EFFICIENCY}

\begin{abstract}
С.К. Сосновський, В.П. Кравченко. Використання стандартних умов при визначенні ефективності зворотних систем охолодження води 3 вентиляторними та баштовими градирнями. Практично всі промислові підприємства мають зворотні системи охолодження води (ЗСОВ), які суттєво впливають на загальні економічні показники виробництва. Згідно нормативній документації випробування до і після реконструкції ЗСОВ для визначення її ефективності мають проводитися при близьких погодних умовах. Однак сильний вплив цих погодних умов на температуру охолодженої води робить це практично неможливим. Оцінка ефективності роботи градирень здійснюється цілим рядом показників, які важко визначаються на практиці. Метою роботи є розробка методу розрахунку ефективності ЗСОВ з вентиляторними і баштовими градирнями при стандартних параметрах експлуатації. Вперше введено поняття стандартних умов роботи ЗСОВ: атмосферний тиск 100 кПа, проектні теплове і гідравлічне навантаження, температура $25{ }^{\circ} \mathrm{C}$ і відносна вологість повітря 55 \%. Розроблено формулу перерахунку заміряної температури охолодженої циркуляційної води на стандартні умови. Розглянуто ідеальний термодинамічний цикл ЗСОВ. Ефективність роботи ЗСОВ розраховується за допомогою термодинамічного ККД, який визначається відношенням перепаду температури води в градирні до температури холодної води. Для ЗСОВ з декількома градирнями має визначатися результуючий перепад температур та результуюча температура холодної води. Сформульовано закон ефективності випарних охолоджувачів ЗСОВ: «Ефективність зворотної системи охолодження води з вентиляторними і баштовими градирнями однозначно визначається їі термодинамічним ККД, який розраховується при стандартних умовах».

Ключові слова: зворотна система охолодження води, вентиляторні та баштові градирні, стандартні умови, термодинамічний ККД
\end{abstract}

S. Sosnovskiy, V. Kravchenko. Standard conditions to define of the water cooling systems with mechanical-draft and chimneytype towers efficiency. Almost all the industrial enterprises include cooling tower systems (CTS), significantly affecting the overall economic performance of production. According to regulatory documents, tests to determine the efficiency of a cooling tower system before and after reconstruction should be carried out under similar weather conditions. However, the strong influence of weather conditions makes it almost impossible. A lot of indicators that describe the efficiency of CTS is very difficult to determine in practice. The aim of the work is to develop a method for calculating the efficiency of CTS with mechanical-draft and chimney-type cooling towers with standard operating parameters. The concepts of these standard parameters are introduced for the first time: atmosphere pressure $100 \mathrm{kPa}$, project heat and hydraulic loads, temperature $25{ }^{\circ} \mathrm{C}$ and relative air humidity $55 \%$. A formula has been developed for recalculating cold water temperature (CWT) for standard conditions. The ideal thermodynamic cycle of CTS is considered. The efficiency of the cycle is calculated by using the ratio of the range (hot water temperature minus CWT) to the CWT. For CTS with different cooling towers, the resulting range and CWT should be determined. The CTS efficiency law for transpiration coolers is formulated: "The efficiency of a cooling tower systems with mechanical-draft and chimney-type towers is determined by its thermodynamic efficiency, which is calculated under standard conditions".

Keywords: cooling tower systems (CTS), mechanical-draft and chimney-type towers, standard conditions, thermodynamic efficiency

Introduction. Almost all industrial enterprises have water-refrigeration systems, which significantly affect the general economic indicators of production. Therefore, much attention is paid to maintaining the state of the equipment at the appropriate level. Mechanical-draft and chimney-type towers are capable of providing a specific heat build-up of an average of $100 \mathrm{~kW} / \mathrm{m}^{2}$, which is several times higher than that for other types of coolers [1]. The most important condition for the efficient operation of cooling tower systems (CTS) is not only the low potential of cooled water $t_{2}$ (cold water temperature CWT), but also the high range $\Delta t$ (hot water temperature (HWT) minus CWT) and, consequently, the high level of specific heat loss $q$ in the cooler. The efficiency of the equipment operation is greatly influenced by the deposits that occur when the water is evaporated [2]. To increase the efficiency of the production by reducing $t_{2}$ by reducing $\Delta t$, as well as increasing the efficiency of the auxiliary equipment (CTS), increasing $\Delta t$ and allowing $t_{2}$ growth is economically inexpedient. Therefore, the 
most effective is the CTS, in which the maximum possible value of $\Delta t$ will be achieved with the minimum allowable value $t_{2}$ [3].

Analysis of normative documentation for the determination of the efficiency of CTS. The object of the research is to determine the effectiveness of the work of the CTS.

The standard documents on cooling towers $[4,5,6]$ do not lead to the above conclusion. Instead, the work of a cooling tower is proposed to be evaluated on the basis of the so-called thermal balance equation [7]:

$$
G\left(t_{1}-t_{2}\right) c_{p}=A g \lambda^{m}\left(1-c_{p} \frac{t_{2}}{r}\right) V \Delta h_{a v e r},
$$

where $G$ - mass flow rate of water, $\mathrm{kg} / \mathrm{s}$;

$g$ - specific mass flow rate of water, $\mathrm{kg} /\left(\mathrm{m}^{2} \mathrm{~s}\right)$;

$\Delta h_{\text {aver }}$ - average logarithmic difference of air enthalpies, $\mathrm{kJ} / \mathrm{kg}$;

$t_{1}$ - temperature of water at the entrance to a cooling tower, hot water temperature (HWT), ${ }^{\circ} \mathrm{C}$;

$c_{p}$ - specific heat capacity of water, $\mathrm{kJ} /(\mathrm{kg} \cdot \mathrm{deg})$;

$r$ - specific heat of vaporization, $\mathrm{kJ} / \mathrm{kg}$;

$V$-volume of irrigator, $\mathrm{m}^{3}$;

$\lambda$ - the ratio of mass flow of air and water, $\mathrm{kg} / \mathrm{kg}$;

$A$ and $m$ - empirical coefficients.

But if the left-hand side of this imaginary equation is an absolutely correct expression of the total heat loss in the coolers, then its right-hand side is simply a chaotic set of inappropriately interrelated parameters. It is not surprising that determined from the above ratio the efficiency indicator $\beta_{x v}=A g \lambda^{m}$ who, according to the developers, is the ratio of the total heat transfer to the average difference in the heat content of air in the volume of the irrigation, does not allow produce even a rough estimate of the cooling capacity of industrial cooling towers [7].

The cooling schedules in the regulations are the most odious. Obviously, these regulatory charts do not at all reflect the real work of CTS with mechanical-draft cooling towers. After all, the constant value $\Delta t$ and the design heat load q uniquely determine the hydraulic load $q=w \Delta t$, where $w$ is the specific water equivalent equal to the product of the specific hydraulic load on the specific heat capacity of the water $\left(g c_{p}\right)$. Therefore, these graphs illustrate only the relationship of $t_{2}$ with deviations from the design value of the heat load for different air temperatures.

The standard cooling schedule for tower cooling towers, presented in [5], completely ignores the type and height of the sprinkler, the volume and method of water distribution (pressure or trough), the layout and direction of the spray jets.

The statement of the purpose of the calculation of cooling towers in the Handbook for the design of cooling towers is noteworthy: "p.2.30. The ultimate goal of calculating tower cooling towers is usually the definition of CWT ..." and right there "p. 2.31. ... the water temperature at the entrance to the cooling tower HWT and at the exit from it CWT are usually set on the basis of heat engineering calculations of heat exchangers".

No less strange is the calculation of the additional aerodynamic resistance of the cooling tower $\left(K_{\text {fill }}\right)$ when water is supplied to it. However, in practice, the total aerodynamic resistance of a cooling tower, when the air is heated and humidified after the heated water is connected, always decreases, and the efficiency of the fan unit increases. It is this circumstance that in the warm season can significantly increase the air supply by the fan, twisting its blades to a larger angle of attack without the threat of overloading the motor.

Considering the influence of many weather factors on the cooling tower operation, the developers of the standards also completely overlooked that, even with good wind partitions, the wind speed and direction affect its cooling capacity no less than temperature and humidity.

In general, the standard theory of cooling towers has not been able to solve the main problem of determining their effectiveness, declaring two mutually exclusive approaches: "a relative assessment 
of the cooling capacity of a cooling tower, when its working conditions during testing differ from the calculated ones, should be made according to mass transfer coefficient” produce under conditions as similar as possible to the calculated ones" [8]. The cooling of circulating water (CW) in cooling towers under various weather conditions occurs not only due to evaporation in the sprinkler, but also due to convection and thermal conductivity along the entire height of the cooler. It goes under the fill packing, and above it, and even in the water drift eliminator of the cooling tower.

It depends not only on the weather and the sprinkler parameters, but also on the level of water dispersion, the height and radius of the nozzle plume, the uniform distribution of water and air over the cooling area, the direction and speed of the wind, and the degree of recirculation of warm moist air. Finally, from the very building structure of the cooling tower, the need for improvement of which is indicated by the disruption of the air flow under the bearing bolt of the fan unit, and the bypassing of air above the air deflectors.

Consequently, standards based on consideration of some factors of the operation of evaporative coolers and ignoring other equally important factors cannot be used in the design, reconstruction and operation of the relevant CTS.

The aim of the article is to calculate the efficiency of CTS with mechanical-draft and chimneytype cooling towers at standard operating parameters.

To achieve the task it is necessary to solve the following tasks:

1. Enter the standard operating parameters.

2. Develop a methodology for recalculating the performance indicator, determined under real conditions, into standard parameters.

3. Check the proposed method of recalculation by balance tests at industrial facilities.

Standard operating conditions for cooling towers. The following conditions affect the cooling capacity of CTS with mechanical-draft and chimney-type cooling towers:

1. Weather (humidity and air temperature, wind speed and direction, atmospheric pressure).

2. Technological (thermal and hydraulic loads, CTS scheme).

3. Constructive (fill packing, water drift eliminator, fan unit, water sprinkler, building construction of the tower).

Comparison of the effectiveness of different types of cooling towers makes sense only in exactly the same weather and process conditions, since their effect on the cooling of the circulating water is so significant that it can level the coolers with any equipment.

In addition, the determination of the basic parameters of CTS operation under different conditions does not allow for an accurate calculation of the economic effect obtained after the reconstruction of the coolers. So, despite the fact that the specific heat removal in the so-called spray and ejection cooling towers is an order of magnitude lower, they, due to various manipulations with the conditions for measuring the operating parameters, continue to compete with much more efficient traditional spray towers.

Therefore, the introduction of standard operating conditions for CTS is of great practical importance.

Thermal and hydraulic loads on CTS are determined on the basis of thermal calculations of the main process equipment and are design parameters. At the same time, the specific heat load $q$, which is economically justified and complies with the standards, should not be lower than $60 \mathrm{Mcal} /\left(\mathrm{m}^{2} \mathrm{~h}\right)$ for tower and $80 \mathrm{Mcal} /\left(\mathrm{m}^{2} \mathrm{~h}\right)$ for mechanical-draft cooling towers [4].

The optimal values of temperature difference $\Delta t^{\circ} \mathrm{C}$ and specific hydraulic load $g, \mathrm{~m}^{3} /\left(\mathrm{m}^{2} \mathrm{~h}\right)$, are determined by the relation [3]:

$$
\Delta t_{\text {opt }}=g_{\text {opt }}=\sqrt{q} .
$$

At the same time, in electric power industry in accordance with RD 34.22.401-95 "Guidelines for setting up the systems of technical water supply of power plants" per $1 \mathrm{~kW}$ of installed capacity of the cooled main process equipment, depending on its efficiency, $0.16 \ldots 0.20 \mathrm{~m}^{3} / \mathrm{h}$ of circulating water is required. For example, for thermal power plants, the magnitude of water rotation in CTS is less, and for NPPs is more. 
The discrepancy between the actual thermal powers of the heaters and coolers and their design values indicates an inefficient use of industrial equipment [9].

Given the above, the standard hydraulic and heat loads are their design values. Great influence on the work of CTS has a distribution of loads between its coolers. Therefore, in the process of measuring the working parameters, it is necessary to adhere to the constancy of all material and energy flows.

Standard atmosphere pressure is $100 \mathrm{kPa}$. Amendments to the measured characteristics of air humidity at a different pressure are given in the Psychrometric tables.

The wind speed along the air inlet front of less than $0.25 \mathrm{~m} / \mathrm{s}$ has practically no effect on the cooling of the circulating water and can be taken as standard. At the same time, when designing a working platform for a cooler, it is necessary to take into account the direction of the prevailing winds from the point of view of the minimum of recirculation of warm humid air channeled into the atmosphere.

Temperature and relative humidity of the air are the most strongly changing weather parameters and their effect on the cooling of circulating water is very high. Therefore, as standard calculated values, it is advisable to take the average values of $t_{\text {air.st. }}$ and $\varphi_{s t .}$, which deviations from the existing design standards will be minimal. Such rounded air parameters for the 100 largest cities of Eurasia over the last five years are $25{ }^{\circ} \mathrm{C}$ and $55 \%$, respectively.

\section{Setting $t_{2}$ into standard conditions}

The effect on temperature and humidity of the evaporative cooler, as well as their continuous change, is so significant that determining the efficiency of equipment in cooling towers under the same weather conditions seems completely unrealistic. On the other hand, it is hardly rational to build standard weather schedules for a huge number of designs and sizes of cooling equipment operating in various technological conditions. Obviously, there should be a reliable and simple mechanism for recalculating CWT measured in certain weather conditions to the standard air parameters.

It is known that the increase in air temperature at its constant humidity intensifies the evaporation of water, but reduces the rate of convection and heat conduction in a cooling tower. Similarly more humid air at a constant temperature reduces the rate of evaporation of water, but increases cravings in the tower, while providing more efficient heat mass transfer. Such a contradictory effect of temperature and air humidity on the cooling of the circulating water may indicate the existence of a region in which the correction $d=t_{2 s t}-t_{2}\left(t_{2 s t}\right.$ and $t_{2}$ - the CWT under standard and actual weather conditions) will be insignificant and proportional to the actually measured $t_{\text {air }}$ and $\varphi$.

In this regard, the hypothesis was put forward about the linear dependence of $d$ on temperature and humidity:

$$
d=a \cdot t+b \cdot \varphi+c,
$$

there $a, b$ and $c$ - constant coefficients for selected standard conditions $\left(t_{\text {air.st. }}=25{ }^{\circ} \mathrm{C} ; \varphi_{\text {st. }}=55 \%\right)$.

In order to determine these coefficients, the results obtained at the installation of CTS of the extruders of the department of synthetic detergent pastes of the Odessa Superphosphate Plant (Fig. 1) were used. A standard steel mechanical-draft cooling tower with a cooling area of $2 \mathrm{~m}^{2}$ and a supply air fan 06-300 No. 8 (TP Soyuzvodokanalproject No. 901-6-52) was installed as a cooler. The water drift eliminator and the fill packing of the cooling tower were filled with the PR-50 nozzle (UTU 38 002-04458-002-92 with Izv. No. 2 of 12/05/97) made of polyethylene of low pressure and high density 273-9.

Non-standard bronze water sprinklers with a high degree of water dispersion were installed with a torch upwards. Thermal and hydraulic loads on the cooling tower were maintained at $200 \mathrm{~kW} \pm 1 \%$ and $19 \mathrm{~m}^{3} / \mathrm{h} \pm 2 \%$, respectively. The measurements were carried out at windless weather and an atmospheric pressure of 1000 mbar $\pm 0.5 \%$. The results of the closest technological conditions for the measurements are given in Table 1.

After processing by the method of least squares of data, taken in exactly the same technological conditions (positions 2, 3, 4 and 5 of Table 1), an equation was obtained for the above correction:

$$
d=29.5-0.85 t-0.15 \varphi,{ }^{\circ} \mathrm{C} \text {. }
$$




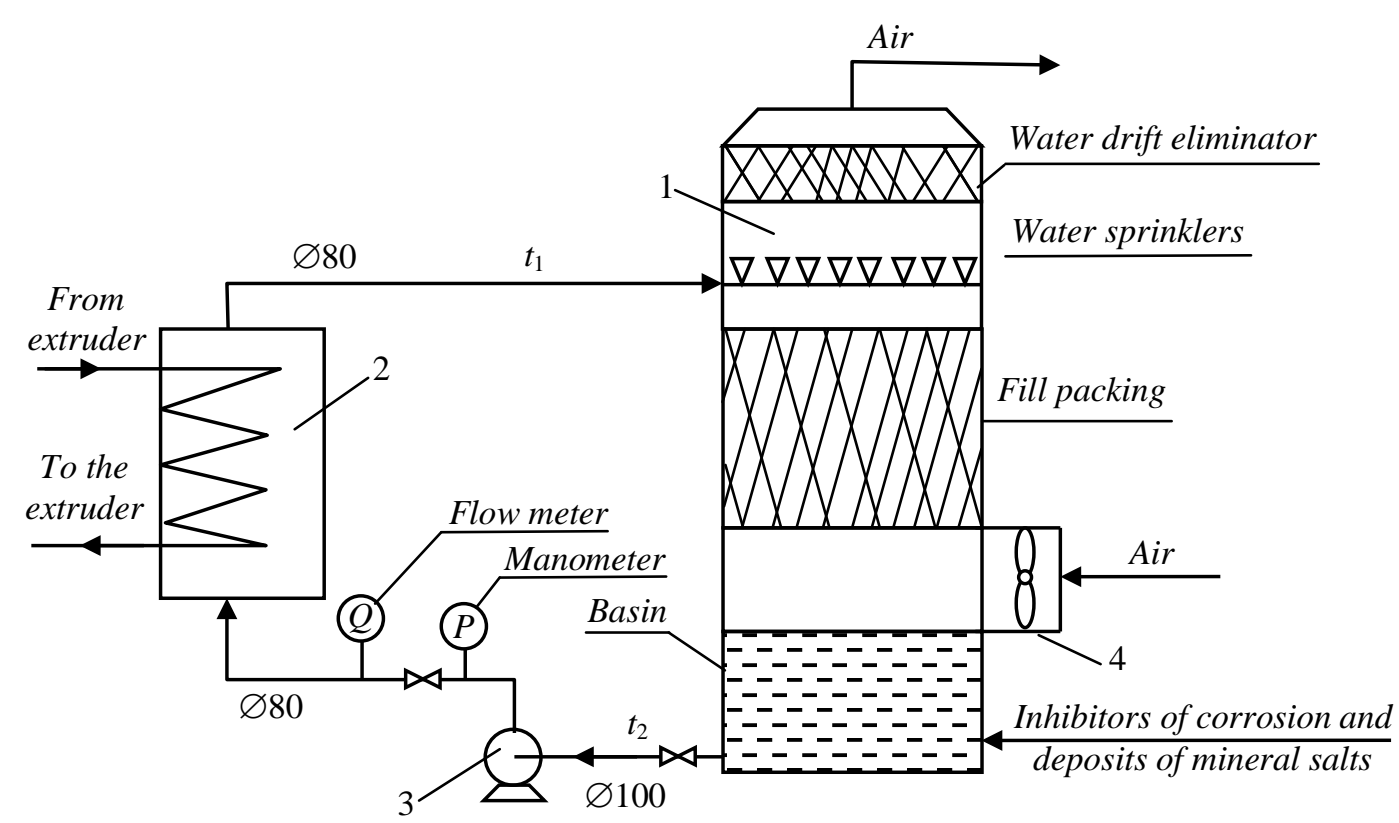

Fig. 1. Scheme of the pilot unit CTS of extruders: 1 - mechanical-draft cooling tower, 2 - shell-and-tube heat exchanger, 3 - centrifugal pump X 20/31-K, 4 - intake fan 06-300 No. 8

Table 1

The measurement results on the CTS pilot installation

\begin{tabular}{|c|c|c|c|c|c|c|}
\hline \multirow[t]{2}{*}{ № } & \multicolumn{6}{|c|}{ Working parameters } \\
\hline & $t_{\text {air. }},{ }^{\circ} \mathrm{C}$ & $\varphi, \%$ & $t_{2},{ }^{\circ} \mathrm{C}$ & $\mathrm{WBT}^{*},{ }^{\circ} \mathrm{C}$ & $\Delta t,{ }^{\circ} \mathrm{C}$ & $d_{\text {meas. }},{ }^{\circ} \mathrm{C}$ \\
\hline 1 & 20 & 45 & 18.50 & 13.70 & 9.25 & 5.50 \\
\hline 2 & 23 & 50 & 21.55 & 16.80 & 9.50 & 2.45 \\
\hline 3 & 25 & 55 & 24.0 & 19.2 & 9.50 & 0.0 \\
\hline 4 & 28 & 60 & 27.30 & 22.50 & 9.50 & -3.30 \\
\hline 5 & 30 & 52 & 27.70 & 22.90 & 9.50 & -3.70 \\
\hline 6 & 35 & 76 & 36.10 & 31.30 & 9.75 & -12.10 \\
\hline
\end{tabular}

The difficulty of further testing the obtained formula on full-scale objects was that it was necessary to measure all the operating parameters of CTS at an air temperature of $25^{\circ} \mathrm{C}$ and its relative humidity of $55 \%$, which are quite rare at the same time and maintained for a relatively short time. But the greatest difficulty was the need to carry out subsequent measurements in exactly the same technological and structural conditions.

The most characteristic results were obtained at enterprises that provided us with the possibility of carrying out balance tests for many years (Table 2).

Further, the formula for converting the measured temperature of the cooled CW to standard conditions was also theoretically confirmed.

Estimated correction $\mathrm{d}$ can be represented as follows:

$$
d=t_{2 s t}-t_{2}=\mathrm{WBT}_{\text {st. }}+\delta_{\text {st. }}-\mathrm{WBT}-\delta,
$$

where $\delta_{\text {st. }}$ and $\delta$ - finite temperature differences (undercooling of circulating water to the theoretical limit) under standard and other conditions, respectively.

The value of $\delta$ depends primarily on the effective operation of the equipment and the design of the cooler. Moreover, it is normalized in a very narrow interval and does not depend on weather and technological conditions [4]. If we also consider a small range of deviations of temperature and air humidity

${ }^{*}$ WBT - water bulb temperature - theoretical limit of water cooling 
from standard conditions, then we can assume with a high degree of accuracy that $\delta_{\text {st. }}=\delta$. In this case, the required correction $\mathrm{d}$ will be equal only to the difference in water bulb temperature (WTB):

$$
d=\mathrm{WBT}_{\text {st. }}-\mathrm{WBT} \text {. }
$$

The more efficient the evaporative cooling mode in the cooling tower, the more accurate this ratio will be.

Table 2

The results of balance tests of production cooling towers

\begin{tabular}{|c|c|c|c|c|c|c|c|}
\hline № & ${ }^{t_{\text {air. }}} \mathrm{C}$ & $\varphi, \%$ & $\begin{array}{l}\text { Measured } \\
\mathrm{CWT},{ }^{\circ} \mathrm{C}\end{array}$ & $\begin{array}{c}\text { Table } \\
\text { WBT, }{ }^{\circ} \mathrm{C}\end{array}$ & $\begin{array}{c}\text { Measured } \\
\Delta t,{ }^{\circ} \mathrm{C}\end{array}$ & $d_{\text {meas. }}\left(d_{\text {calc. }}\right),{ }^{\circ} \mathrm{C}$ & $\begin{array}{c}G, \\
\mathrm{~m}^{3} / \mathrm{h}\end{array}$ \\
\hline \multicolumn{8}{|c|}{ Kremenchug thermal power station, chimney-type cooling tower, $S_{\text {cool. }}=1280 \mathrm{~m}^{2}$} \\
\hline 1 & 25 & 55 & 26.5 & 19.2 & 8.0 & 0 & 7000 \\
\hline 2 & 24.8 & 46 & 25.8 & 17.7 & 7.0 & $0.7(1.5)$ & 8000 \\
\hline 3 & 20 & 71 & 24.7 & 16.9 & 7.0 & $1.8(1.9)$ & 8000 \\
\hline 4 & 26 & 58 & 27.8 & 20.5 & 8.0 & $-1.3(-1.3)$ & 7000 \\
\hline \multicolumn{8}{|c|}{ Odessa port plant, mechanical-draft cooling tower, $S_{\text {cool. }}=144 \mathrm{~m}^{2}$} \\
\hline 1 & 25 & 55 & 29.2 & 19.2 & 12 & 0 & 4500 \\
\hline 2 & 26 & 66 & 31.6 & 21.6 & 12.5 & $-2.4(-2.5)$ & 4300 \\
\hline 3 & 24 & 62 & 29.4 & 19.3 & 13.1 & $-0.2(-0.2)$ & 4100 \\
\hline 4 & 20 & 54 & 24.8 & 14.8 & 12 & $4.4(4.4)$ & 4500 \\
\hline \multicolumn{8}{|c|}{ JSC “Ukrtatnafta”, mechanical-draft cooling tower, $S_{\text {cool. }}=192 \mathrm{~m}^{2}$} \\
\hline 1 & 25 & 55 & 24 & 19.2 & 4.8 & 0 & 356 \\
\hline 2 & 21.8 & 66 & 22.6 & 17.8 & 4.8 & $1.4(1.1)$ & 356 \\
\hline 3 & 24 & 60 & 23.9 & 19.0 & 4.9 & $0.1(0.1)$ & 350 \\
\hline \multicolumn{8}{|c|}{ Zaporizhzhya NPP chimney-type cooling tower, $S_{\text {cool. }}=10000 \mathrm{~m}^{2}$} \\
\hline 1 & 25 & 55 & 30.0 & 19.2 & 9.8 & 0 & 94675 \\
\hline 2 & 20 & 54 & 25.6 & 14.8 & 9.8 & $4.4(4.4)$ & 94675 \\
\hline
\end{tabular}

In Table 3 shows the recalculation of WBT for various $t_{\text {air. }}$ и $\varphi$ for standard conditions using the amendment $d$.

Table 3

Recalculation of air temperature by wetted thermometer to standard conditions

\begin{tabular}{c|c|c|c|c|c|c}
\hline$t_{\text {air. }}$, & \multicolumn{7}{c}{$\varphi, \%$} \\
\cline { 2 - 7 }${ }^{\circ} \mathrm{C}$ & 30 & 40 & 50 & 55 & 60 & 70 \\
\hline 15 & $8.0+12.3=20.3$ & $9.1+10.7=19.8$ & $10.1+9.2=19.3$ & $10.7+8.5=19.2$ & $11.2+7.8=19.0$ & $12.2+6.3=18.5$ \\
\hline 20 & $11.7+8.0=19.7$ & $13.0+6.5=19.5$ & $14.3+5.0=19.3$ & $14.9+4.25=19.15$ & $15.5+3.5=19.0$ & $16.7+2.0=18.7$ \\
\hline 25 & $15.3+3.75=19.05$ & $16.9+2.25=19.15$ & $18.4+0.75=19.15$ & 19.15 & $19.85-0.75=19.1$ & $21.25-2.25=19$ \\
\hline 30 & $18.9-0.5=18.4$ & $20.8-2.0=18.8$ & $22.55-3.5=19.05$ & $23.4-4.25=19.15$ & $24.2-5.0=19.2$ & $25.75-6.5=19.25$ \\
\hline 35 & $22.5-4.8=17.7$ & $24.7-6.2=18.5$ & $26.7-7.7=19.0$ & $27.6-8.5=19.1$ & $28.55-9.25=19.30$ & $30.3-10.8=19.5$ \\
\hline
\end{tabular}

The maximum deviation of the calculated value of $\mathrm{WBT}_{\text {st. }}$ from its tabular value in the selected area is only $0.15{ }^{\circ} \mathrm{C}$, or $0.78 \%$, which indicates the high accuracy of the formula obtained in the air temperature range from 15 to $35^{\circ} \mathrm{C}$ and its humidity from 50 to $60 \%$. Measurements at $25{ }^{\circ} \mathrm{C}$ increase the allowable calculated range of air humidity from 30 to $70 \%$.

It is important to note that the function $d=f\left(t_{\text {air. }} ; \varphi\right)$ is monotonous. Therefore, all intermediate values of $\mathrm{WBT}_{\text {st. }}$ located inside the marked range of air temperature and its humidity also correspond to the above error.

As was shown by the example of industrial facilities, the calculation of the correction $\mathrm{d}$ only as the difference in air temperature from the wetted thermometer outside the selected range (Table 2) does not 
ensure the specified accuracy of the results. Therefore, in practice, the reduced calculation formula and Psychrometric tables both should be used only within the given limits of weather conditions.

CTS performance indicator. Obviously, the most effective will be coolers, the design of which provides the highest cooling rate of $\mathrm{CW} v_{t}=d t / d \tau=\max$, where $\tau$ is time.

In Fig. 2 shows the ideal thermodynamic cycle of CTS with one cooler in the coordinates of TemperatureTime [10]. For CTS with several cooling towers, the resulting temperature difference should be determined [9]:

$$
\Delta t_{\text {res }}=\frac{\sum_{i=1}^{n} \Delta H_{\text {i.heater }}}{\sum_{i=1}^{n} W_{\text {i.heater }}}=\frac{\sum_{i=1}^{m} Q_{\text {i.cooler }}}{\sum_{i=1}^{m} W_{\text {i.cooler }}},
$$

where $\Delta H_{\text {i.heater }}$ and $Q_{\text {i.cooler }}$ - thermal power, MW, and $W_{\text {i.heater }}$ and $W_{\text {i.cooler }}-$ water equivalents, MW/deg, flows of $C W$ through $\mathrm{n}$ heaters and $\mathrm{m}$ coolers, respectively.

According to the law of conservation of energy, the resulting temperature drops in coolers and heaters under sta-

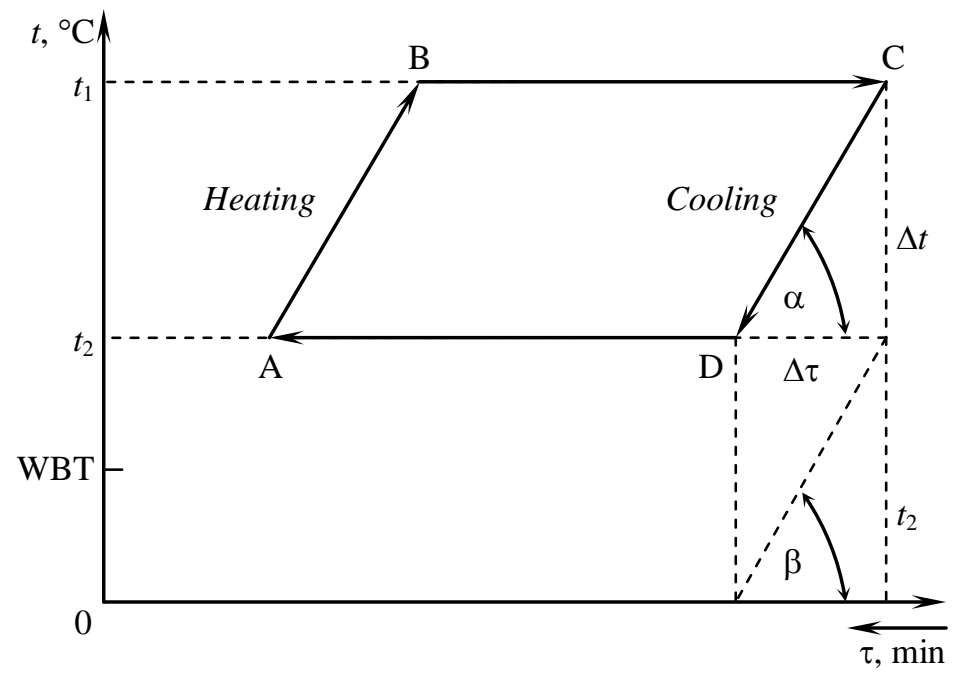

Fig. 2. The ideal thermodynamic CTS cycle tionary conditions are equal. This stationary cycle corresponds to the established thermodynamic equilibrium under constant weather and technological conditions, when the heating rate of the circulating water is equal to the rate of its cooling (sections $\mathrm{AB}$ and $\mathrm{CD}$ ). The flow of water through pipelines is isothermal (sections $\mathrm{BC}$ and $\mathrm{AD}$ ).

As can be seen from the figure, the cooling rate of the circulating water required to determine the efficiency of the water-cooling system is $v_{t}=\Delta t / \Delta \tau=\operatorname{tg} \alpha$, where $\Delta \tau$ is the time that water is in the cooler. Due to the large irregularity of water and air distribution in natural cooling towers, the determination of the exact value of $\Delta \tau$ is not possible. Therefore, it is advisable to calculate the relative cooling rate of $\mathrm{CW}$, defined as the ratio of the actual speed to its maximum possible value under the given conditions.

It is known that in the warm season the temperature difference $\Delta t$ never exceeds the temperature of the cooled water $t_{2}$. In other words, the cooling rate of water at $\Delta t=t_{2}$ at this time is the technological limit for mechanical-draft and chimney-type cooling towers:

$$
v_{\text {tmax }}=t_{2} / \Delta \tau=\operatorname{tg} \beta \text {. }
$$

Here $v_{t} / v_{t \max }=\operatorname{tg} \alpha / \operatorname{tg} \beta=\Delta t / t_{2}=\eta$.

Therefore, the degree of approximation of the actual cooling rate to its maximum possible value under given conditions is determined by the proportionality coefficient $\eta$, which is the thermodynamic efficiency of the cycle. Therefore, its calculation with standard weather and technological parameters is a necessary condition for determining the efficiency of the CTS.

In addition, it is important to note that, in contrast to the above normative heat balance equation, the actual CTS heat balance equation has the following form:

$$
G \cdot \Delta t_{\text {res. }} \cdot c_{p}=\sum_{i=1}^{m} Q_{\text {i.cooler }} Q_{\text {pipe. }}+Q_{w r b} \pm Q_{\text {feed. }},
$$

where $Q_{\text {pipe. }}$ - heat losses in pipelines, fittings and pumps;

$Q_{w r b}$ - heat losses in the water receiving basins (for two-lifting CTS schemes);

$Q_{\text {feed. }}$ - heat losses or heating of the CW when it is feeding and reagent processing.

The resulting CWT depends not only on the thermal balance of CTS under fixed weather and process conditions, but also on the structure of CTS itself. 
For example, schemes for feeding circulating water with stripping condensate into the cooling tower basin or in the supply conduits give significant discrepancies in the measurements of CWT. The redistribution of the hydraulic load between the different chillers included in the CTS has a great influence on $t_{2}$. Therefore, the resulting temperature of the cooled CW is a function of many interdependent variables:

$$
t_{\text {2res. }}=F\left(Q_{\text {i.cooler }} ; Q_{\text {pipe. }} ; Q_{w r b} ; Q_{\text {feed. }} ; W_{i}\right) \text {. }
$$

In the case of the constancy of all variables in brackets with constant weather and technological parameters for each individual CTS of a fixed structure, you can write:

$$
\frac{\sum_{i=1}^{m} Q_{i . c o o l e r}+Q_{\text {pipe. }}+Q_{w r b} \pm Q_{\text {feed. }}}{G \cdot c_{p}}=\eta \cdot t_{\text {res. }},
$$

where $\eta$ - coefficient of proportionality under standard conditions.

Here $\Delta t_{\text {res. }}=\eta \cdot t_{2 \text { res. }}$ and $\eta=\Delta t_{\text {res. }} / t_{2 \text { res. }}$.

This means that under standard operating conditions of the CTS, the coefficient $\eta$ is nothing but its thermodynamic efficiency, which takes into account all the components of the heat balance and is therefore a sufficient condition for determining the efficiency of the system.

Thus, it is possible to formulate the following law of CTS efficiency: "The efficiency of a water cooling tower system with mechanical-draft and chimney-type cooling towers is determined by its thermodynamic efficiency, calculated under standard conditions.”

Therefore, it can be argued that the only large range $\Delta t$ is not an indicator of the efficiency of CTS, since it is freely achieved by increasing the heat load or reducing the hydraulic load. In turn, only a low value of the CWT cannot be such an indicator because it easily decreases with an increase in hydraulic load or a drop in heat.

In addition, the high value of the thermodynamic efficiency in the cold season also does not indicate the effective operation of the CTS equipment, since it eliminates the design features of the coolers.

Currently, in systems with serviceable cooling towers under standard conditions, the thermodynamic efficiency is $0.35 \ldots 0.50$ for mechanical-draft and $0.20 \ldots 0.40$ for chimney-type cooling towers.

\section{Conclusions.}

1. Introduced the concept of standard operating conditions of the mechanical-draft and chimneytype cooling towers of cooling tower systems.

2. A formula has been developed for recalculation of the measured of the cold water temperature to standard conditions.

3. The law of efficiency of cooling tower systems is formulated.

\section{Литература}

1. Amer O., Boukhanouf R., Ibrahim H.G. A Review of Evaporative Cooling Technologies. International Journal of Environmental Science and Development. 2015. Vol. 6, No. 2. P. 111-117. DOI: 10.7763/IJESD.2015.V6.571.

2. Исследование интенсивности коррозии и накопления отложений при упаривании циркуляционной воды в промышленных оборотных системах охлаждения / Чиченин В.В., Кишневский В.А., Грицаенко А.С., Савич С.Л., Шуляк И.Д. Восточно-Европейский журнал передовых технологий. 2015. № 6/8(78). C. 34-40. DOI: 10.15587/1729-4061.2015. 54752.

3. Sosnovskii S.K., Kravchenko V.P. The Efficiency Index of Mechanical-draft and Chimney-type Water Cooling Towers Operation. Thermal Engineering. 2014. Vol. 61, No. 9. P. 636-641.

4. СНИП 2.04.02-84. Водоснабжение. Наружные сети и сооружения / Госстрой СССР. - М.: Стройиздат, $1985.136 \mathrm{c}$.

5. Руководство по проектированию градирен. Госстрой СССР. Москва : Союзводоканалпроект. 1980. $142 \mathrm{c}$.

6. Пособие по проектированию градирен (к СНиП 2.04.02-84). Москва : ЦИТП, 1989. 192 с.

7. Бучков А.М. Об эффективности систем технического водоснабжения. Энергетик. 2005. № 10. С. 6-8.

8. Гладков В.А., Арефьев Ю.И., Пономаренко В.С. Вентиляторные градирни. Москва, 1976. 216 с. 
9. Сосновский С.К., Кравченко В.П. Термодинамические циклы и правила регулирования систем оборотного водоснабжения с испарительными градирнями. Холодильная техника и технология. 2015. Т. 51, № 6. С. 51-60.

10. Сосновский С.К., Кравченко В.П. Некоторые теоретические аспекты эксплуатации оборотных систем охлаждения воды с вентиляторными и башенными градирнями. Энергетика и электрификация. 2014. №12, С. 39-44.

\section{References}

1. Amer, O., Boukhanou, f. R., \& Ibrahim, H. G. (2015). A Review of Evaporative Cooling Technologies. International Journal of Environmental Science and Development, 6, 2, 111-117. DOI: 10.7763/IJESD.2015.V6.571.

2. Chichenin, V.V., Kishnevsky, V.A., Gritsayenko, A.S., Savich, S.L., \& Shulyak I.D. (2015). Investigation of the intensity of corrosion and sediment accumulation during evaporation of circulating water in industrial circulating cooling systems. East European Journal of Advanced Technologies, 6/8(78), 34-40. DOI: 10.15587/1729-4061.2015. 54752.

3. Sosnovskii, S.K., \& Kravchenko, V.P. (2014). The Efficiency Index of Mechanical-draft and Chimneytype Water Cooling Towers Operation. Thermal Engineering, 61, 9, 636-641.

4. SNiP 2.04.02-84. Sanitary norms and rules 2.04.02-84. Water supply. External networks and facilities. (1985). Gosstroy USSR. Moscow: Stroiizdat.

5. Manual for the design of cooling towers. (1980). Gosstroy USSR. Moscow: Soyuzvodokanalproekt.

6. Manual for the design of cooling towers (to SNiP 2.04.02-84). (1989). Moscow: TSITP.

7. Bychkov, A.M. (2005). On the effectiveness of technical water supply systems, Energetik, 10. 6-8.

8. Gladkov, V.A., Aref'yev, Yu.I., \& Ponomarenko, V.S. (1976). Mechanical draft cooling towers. Moscow.

9. Sosnovskiy, S.K., \& Kravchenko, V.P. (2015). Thermodynamic cycles and rules for regulating circulating water supply systems with evaporative cooling towers. Kholodil'naya tekhnika $i$ tekhnologiya, 51, 6, 51-60.

10. Sosnovskiy, S.K., \& Kravchenko, V.P. (2014). Some theoretical aspects of the operation of circulating water supply systems with mechanical draft and chimney cooling towers. Energetika i elektrifikatsiya, 12, 39-44.

Сосновський Сергій Костянтинович; Sosnovskii Sergei, ORCID: https://orcid.org/0000-0001-8791-9324

Кравченко Володимир Петрович; Kravchenko Volodymyr, ORCID: http://orcid.org/0000-0002-7557-3327

Received December 5, 2018

Accepted December 17, 2018 